\title{
Bioenergy Sources and Representative Case Studies in Mexico
}

Gibrán S Alemán-Nava ${ }^{1}$, Luisaldo Sandate-Flores ${ }^{1}$, Alexander Meneses-Jácome ${ }^{2}$, Rocío Díaz-Chavez ${ }^{3}$, Jean-Francois Dallemand ${ }^{4}$ and

\section{Roberto Parra ${ }^{1 *}$}

${ }^{1}$ Department of Environmental Bioprocesses, Water Center for Latin America and the Caribbean, Mexico

${ }^{2}$ Environmental Engineering, St. Thomas University, Bucaramanga, Colombia

${ }^{3}$ Centre for Environmental Policy, Imperial College London, London SW7 1NA, UK

${ }^{4}$ European Commission, Joint Research Centre, Institute for Energy, Via E. Fermi 2749, TP 450, 21027 Ispra (Va), Italy

\begin{abstract}
Energy policies during the last years have tried to promote the use and development of renewable energy, with bioenergy representing the highest potential. It is estimated that this source could supply $40 \%$ of primary energy consumption in Mexico, with a potential production of 3,569 PJ/year. Attempts to exploit biomass energy in Mexico have encouraged the development of various technologies, focused mainly in the production of biogas, biodiesel and improvement of wood stoves and charcoal furnaces. These technologies have relevant projects throughout the country. Biogas has been generated using landfills, swine waste and wastewater. Biodiesel has been produced from different sources such as, oleaginous crops, recycled oil or animal tallow. Finally, since the use of firewood as heating and cooking source is widely used in Mexico (27 million people), development of this technology has also played an important role in the exploitation of bioenergy as well as the improvement of charcoal furnaces. This paper presents an overview of the potential of bioenergy potential and presents main case studies in Mexico.
\end{abstract}

Keywords: Bioenergy; Biogas; Biodiesel; Firewood; Charcoal

\section{Introduction}

The Energy Reform, recently approved by the Congress of the Union at the end of 2013, has allowed the creation of a fund, after covering $4.7 \%$ of GDP based on the year 2013, to strengthen renewable energy sources. Specifically, $10 \%$ of this fund will be used to finance projects in science, technology and renewable energy sources, and 10\% will fund scholarships for development of human capital through postgraduate formation; however roadmaps to define energy production from each renewable energy are still missing [1]. Four main legal instruments are expected to promote renewable energy in Mexico. One is the recent Energy Reform approved by the Congress of the Union. The second instrument is the General Law for Climate Change adopted in May 2012 , which sets the goal of $35 \%$ of energy generated in the country should come from renewable sources by 2024 [2]. The third legal instrument is the law of Promotion and Development of Bioenergy in order to achieve energy diversification and sustainable development in the production of energy [3,4]. Finally, the law for the Use of Renewable Energy and Finance of the Energy Transition recently modified and approved [5]. This law establishes, among other issues, the legal aspects and conditions for the use of renewable energy and clean technologies as well as reducing the use and dependency of fossil fuels. For instance, adding $2 \%$ of ethanol to gasoline in Guadalajara, Monterrey and Mexico City was introduced at the end of 2012 [6]. These four legal instruments are expected to create a better framework to support renewable energy in general and also a future green economy in Mexico.

According to the Global Status Report 2013 [7], the global energy consumption in 2011 was estimated at 471.8 exajoules (EJ), with fossil fuels supplying $78.2 \%$, nuclear power supplying $2.8 \%$, and renewable energy supplying about $19 \%$ of the global final energy demand; this is divided as follows $9.7 \%$ came from modern renewable sources, including hydropower, wind, solar, geothermal and biofuels. Traditional biomass, which is used primarily for cooking and heating in rural areas of developing countries, and could be considered renewable, accounted for approximately $9.3 \%$ of the total final energy demand. According to the national energy databases [8], Mexico produced 219.5 million tons of oil-equivalent energy during 2011. An estimated $88.7 \%$ came from fossil fuels, $6.9 \%$ from renewable sources, $3.17 \%$ from charcoal and the remaining $1.3 \%$ from nuclear sources (Figure 1). The use of biomass as a primary source of bioenergy has been decreasing in Mexico since 1965 , when it constituted $15.3 \%$ of the total primary energy supply. This share represented only $5.3 \%$ in 2005 [8]. This is mainly because firewood is mainly used by rural communities in the country [9] who use it for cooking and heating purposes. However, the rural population has decreased from almost 50\% in 1960 to $21 \%$ in 2013 [10,11]

Almost three quarters of the publications on renewable energy in Mexico, during the last 30 years, have focused on biomass research [1] These publications have tackled different topics including management of woody biomass [12,13], biofuels (biodiesel, bioethanol) [14-16], biogas production $[17,18]$, greenhouse gas mitigation from biomass utilization [19], biomass stoves [20-22], agricultural residues [23] among others. However, it is hard to find a paper which includes successful studies on a large scale in the country. In this context, this work gathers important information from studies, published articles and national reports about bioenergy potential and presents main case studies in Mexico.

\section{Bioenergy Potential in Mexico}

Worldwide, Mexico was ranked sixth, as crude oil producer, and eighteenth as natural gas producer in 2009 [24]. Although Mexico is a producer of crude oil, there are serious problems regarding the supply of finished petroleum products. Primarily, the origin of these problems comes from the lack of investment to increase refining capacity in the

*Corresponding author: Roberto Parra, Department of Environmental Bioprocesses, Water Center for Latin America and the Caribbean, Mexico, Tel: 5281-8358 2000, Ext. 5561-105; E-mail: r.parra@itesm.mx

Received July 11, 2014; Accepted August 18, 2014; Published August 25, 2014

Citation: Alemán-Nava GS, Sandate-Flores L, Meneses-Jácome A, Díaz-Chavez R, Dallemand JF, et al. (2014) Bioenergy Sources and Representative Case Studies in Mexico. J Pet Environ Biotechnol 5: 190. doi:10.4172/2157-7463.1000190

Copyright: () 2014 Alemán-Nava GS, et al. This is an open-access article distributed under the terms of the Creative Commons Attribution License, which permits unrestricted use, distribution, and reproduction in any medium, provided the original author and source are credited. 


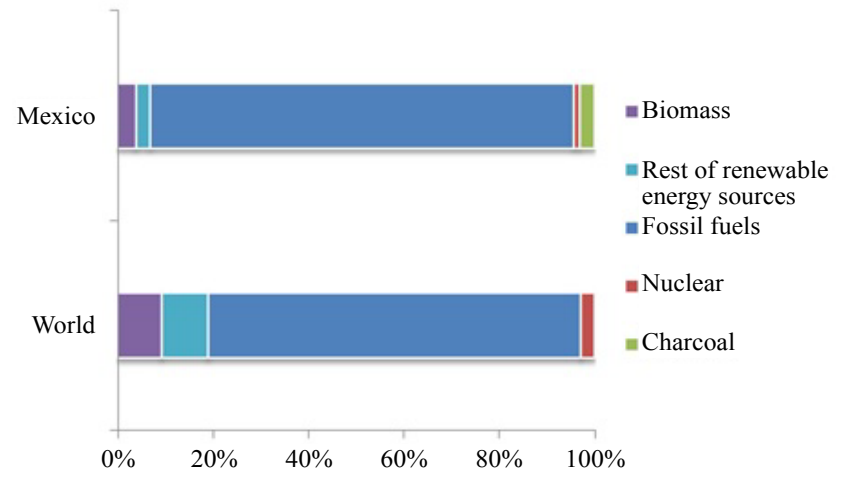

Figure 1: Energy share of global and Mexico final energy consumption in 2011.

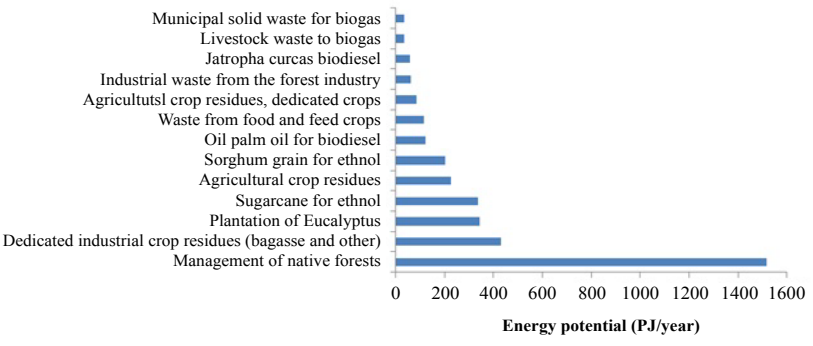

Figure 2: Biomass energy potential divided by sources in Mexico

country and, also from the lack of diversification of energy sources [4].

Previous studies show that bioenergy may be increased substantially in order to reach up to $16.17 \%$ of Mexico's total energy supply for electricity generation, transportation and rural residential sectors by $2030[25,26]$. It is also important to point out that Mexico is the third largest country in Latin American and the Caribbean in terms of cropland area [27]. By 2006, it was estimated that Mexico had 75.3 million tons of dry matter from crop residues that potentially could be transformed into bioenergy, Valdez-Vazquez et al. detected thirty five Mexican municipalities with a high estimated bioenergy potential (280,320 to 2,181,021 tons of dry matter per year) [26]. The Mexican Ministry of Energy estimated that the potential energy per year in 2030 would be 85,500-119,498 MW from biomass, but in 2013 the installed capacity was only $645 \mathrm{MW}$ in the country [28].

The scenarios for mitigation of emissions show that bioenergy can play a key role in the energy supply in the medium and long term. The German Advisory Council on Global Change (WBGU, for its initials in German) estimated the potential of bioenergy in the global energy system to be between 80 and $170 \mathrm{EJ}$, equivalent to $17 \%-36 \%$ of primary energy consumption in the world in 2008 [29]. There is great potential in biomass as energy resource. In a detailed study on the reduction of carbon emissions in Mexico, financed by the World Bank, the energy potential of the main sources of bioenergy available in the country [30] was evaluated (Figure 2) as equivalent to 3,569 PJ/year, or $42 \%$ of the country's primary energy consumption in 2008. It is important to point out that these estimations were based on suitable lands for each crop mentioned in Figure 2 and excluded those a) used for agriculture, b) covered by forests, jungles and other natural hedges, c) belong to conservation areas and d) non arable because they have a slope higher than $4-12 \%$ [31].

\section{Case Studies in México}

There are several pathways for direct combustion, gasification, fermentation and anaerobic digestion allowing the use of biomass as a sustainable energy source [32]. There is significant experience in the area of bio-digesters, methane capture and electricity generation in landfills [17], as well as efficient wood stoves for cooking in rural areas in Mexico. Furthermore, there are emerging initiatives for liquid biofuels, particularly biodiesel, and also research groups working in materials and processes for biofuels for first, second and third generation [33,34]. Different successful bioenergy cases were researched in Mexico for big and small scales, as mentioned below.

\section{Biogas}

Gaseous biofuels are classified according to their procurement processes. Such processes may be biological, to generate biogas or thermochemical to produce syngas (synthesis gas). Biogas can be used as fuel in stoves and boilers; for domestic lighting and heating, and to fuel internal combustion engines or gas turbines, generating power or electricity. In the case of Mexico, the country has relevant experience on biological methods for biogas production (Table 1).

Biogas from landfill: Bioenergy Nuevo Leon, SA de CV (BENLESA) is the first project in Mexico and Latin America using biogas as renewable energy produced from a landfill. BENLESA is the result of a partnership between private enterprise Bioeléctrica Monterrey, SA de CV and the government of the State of Nuevo León, through the System Management and Processing of Organic Waste (SIMEPRODE), a public agency, and Bioeléctrica Monterrey and International Energy Systems, S.A. de C.V. (SEISA). These companies are completely Mexican, subsidiaries of the Group Gentor. SEISA has extensive experience in the area of generating clean energy through cogeneration projects [35].

Biogas from swine waste: The Agricultural Development Corporation of Nuevo León opened in August 2006 on the farm "El Chancho", Cadereyta, the first of three electricity generating plants using biogas. The initiative includes a set of nine pig farms in the municipalities of Cadereyta, Allende and Montemorelos. These farms have mitigated their methane emissions to the atmosphere through the capture and burning of biogas generated by digestion of swine manure. The project began as a response to the problem of manure disposal, the impact on production costs because ofthe large increase in volume due to water during the rainy season. It seeks to use pig manure for: a) obtaining biogas, b) generate electricity for consumption, c) sell surplus energy to the national grid (CFE), and d) obtain usable organic sludge as an agricultural fertilizer $[29,36]$.

Biogas from wastewater treatment: The proposal raised to address the need to reduce Biological Oxygen Demand (BOD) and thus reduce the energy cost of the aerobic phase [38] of wastewater treatment plants from slaughterhouse "TIF 333". For the slaughterhouse, the amount of biogas produced was not a priority, but there was the possibility of using it as energy in the boiler, consuming up to $150 \mathrm{~m}^{3} / \mathrm{d}$. Pretreatment reduces the incoming $\mathrm{BOD}$ from 4,700 $\mathrm{ppm} \mathrm{O}_{2}$ to $2012 \mathrm{ppm} \mathrm{O}_{2}$ at the outlet. In the final issue of $612 \mathrm{ppm} \mathrm{BOD,} \mathrm{O}_{2}$ is achieved. Although 150 $\mathrm{m}^{3}$ of biogas/d is used in the boiler, the total generation is $157 \mathrm{~m}^{3}$ of biogas/d [29,37].

\section{Efficient wood stoves}

About 2 billion people worldwide rely on biomass for cooking and heating. In Mexico, the use of firewood represents about $10 \%$ of primary 


\begin{tabular}{|c|c|c|c|c|}
\hline Project & Location & Start date & Capacity & Source of energy \\
\hline Biogas from landfill & Salinas Victoria, Nuevo León & 2009 & 7.4 MW (2003), $12.72 \mathrm{MW}$ (2007), $15.9 \mathrm{MW}$ (2010) & Biogas from muynicipal waste \\
\hline Biogas from swine waste & Cadereyta, Nuevo Leon & 2005 & $65 \mathrm{~kW}$ & Pig farm manure \\
\hline $\begin{array}{c}\text { Biogas from wastewater } \\
\text { treatment }\end{array}$ & León, Guanajuato & 2008 & 2 plants of $55 \mathrm{~kW}$ & Cattle manure \\
\hline
\end{tabular}

Table 1: Projects for biogas production.

\begin{tabular}{|c|c|c|c|c|}
\hline Project & Location & Start date & Size & Characteristics \\
\hline Patsari stove & Michoacán and 15 more states & 2003 & $\begin{array}{c}105 \mathrm{~cm} \times 70 \\
\mathrm{~cm} \times 27 \mathrm{~cm}\end{array}$ & $\begin{array}{c}\text { The exterior is made of brick which includes an optimized } \\
\text { combustion chamber and tunnels to reduce the production of } \\
\text { emissions. }\end{array}$ \\
\hline Mexalitl stove & $\begin{array}{c}\text { Nuevo Leon, Chihuahua, State of Mexico and } \\
\text { Yucatan }\end{array}$ & 2008 & $35 \mathrm{~cm} \times 70 \mathrm{~cm}$ & $\begin{array}{c}\text { The exterior is made of concert with a combustion chamber of } \\
\text { ceramic. }\end{array}$ \\
\hline ONIL stove & $\begin{array}{c}\text { Chiapas, Oaxaca, Veracruz, Puebla, Hidalgo, } \\
\text { State of mexico, Queretaro and Guanajuato }\end{array}$ & 2010 & $\begin{array}{l}80 \mathrm{~cm} \times 54 \\
\mathrm{~cm} \times 20 \mathrm{~cm}\end{array}$ & Stove made from cement, sand and iron with a volume of $15 \mathrm{~L}$. \\
\hline
\end{tabular}

Table 2: Projects for use of wood stoves.

\begin{tabular}{|c|c|c|c|c|}
\hline Project & Location & Start date & Capacity & Caracteristics \\
\hline $\begin{array}{c}\text { Brick } \\
\text { furnaces }\end{array}$ & $\begin{array}{l}\text { Tamaulipas, Jalisco, Queretaro, Hidalgo, } \\
\text { Guanajuato, Campeche, Tabasco y Quintana Roo }\end{array}$ & 2003 & $\begin{array}{l}6 \mathrm{~m}^{3} \text { of wood. Productivity: } 1,300-2,300 \text { of } \\
\text { charcoal, depending on moisture of wood. }\end{array}$ & $\begin{array}{l}\text { Internal diameter: } 3.2 \mathrm{~m} \text {, internal height: } \\
2.20 \mathrm{~m} \text {, capacity: } 6 \mathrm{~m}^{3} \text { of wood }\end{array}$ \\
\hline
\end{tabular}

Table 3: Projects for use of charcoal furnaces.

\begin{tabular}{|c|c|c|c|c|}
\hline Project & Location & Start date & Capacity \\
\hline Bioenergetic Chiapas & Chiapas & 2009 & 2,000 L/d (Tuxtla Gutierrez), 8,000 L/d (Puerto Chiapas), 20,000 & Palm oil and Jatrophacurcas \\
\hline $\begin{array}{c}\text { BiocombustiblesInternacionales S.A. } \\
\text { de C.V. }\end{array}$ & Nuevo Leon & 2005 & 1.5 million L/d & Animal thallow and recycled oil \\
\hline
\end{tabular}

Table 4: Projects for biodiesel production.

energy and contributes $46 \%$ of the energy demanded by the residential sector [39]. In Mexico, firewood is used by over 27 million people, $89 \%$ of the rural population uses wood as the main fuel for cooking, while in urban areas firewood users represent $11 \%$ of the population [40]. There are various projects developed in Mexico (Table 2):

Patsari stove: The Interdisciplinary Group for Appropriate Rural Technology A.C. in collaboration with the Center for Ecosystem Research has promoted, since 2003, the use of the very efficient wood stove "Patsari" as a means to reduce adverse impacts to health and the environment, and promoting sustainable use of firewood in Mexico, and thereby improving the quality of life of rural families. Patsari means "the one who keeps" in the Purépecha language, referring to the way it works, storing heat, and so preserving user's health and sustainability of forests. It is constructed in situ, combining the use of both local and commercial materials. It achieves high efficiency, resulting in higher levels of adoption among users, shorter construction times and durability. The project is implemented in Michoacán and 15 other Mexican states, and it has 5 main components: a) innovation and technology development; b) dissemination of efficient stoves; c) development of local small businesses; d) monitoring and impact assessment e) strengthening the program. It has been quantified that each Patsari stove can mitigate between 3.0 and $8.5 \mathrm{tCO}_{2}$ eq/year, depending on the user type and the renewability of the firewood used $[20,41]$.

Mexalit stove: This stove has a weight of $76 \mathrm{~kg}$, thus facilitating its distribution. The volume of the chamber is $15 \mathrm{~L}$ for a capacity of up to $3.5 \mathrm{~kg}$ of wood. It was designed to reduce from $50 \%$ to $60 \%$ fuel consumption, compared to traditional open stoves, and to improve combustion heat. The main burner is located at the center point of the generation of the flame. The chamber height generates maximum use of the flame at any time, allowing the heat to continue once the flame is extinguished due to the accumulated heat inside the stove, since the interior is lined with mud-manufactured bricks [42].

Onil stove: this stove was designed using the principles of combustion "Rocket elbow" developed by Dr. Larry Winiarski of Aprovecho Research Center, Oregon. These principles have been used to create many ecological stoves currently used in the world. The stove and each of its components were tested for one year in the community of Santa Avelina (Guatemala) to ensure that needs have families were covered and at the same time met the requirements of quality, functionality and durability. Permanent adjustments and improvements have been made to ensure technology acceptance and adoption. There have been so far more than 16,720 stoves installed in 9 states of Mexico [29,43,44].

\section{Efficient charcoal furnaces}

An estimated ten million urban households use charcoal in Mexico. Charcoal is produced mainly in traditional earth kilns with low transformation efficiency of coal burning (only $12 \%$ to $20 \%$ of the dry weight of the wood is recovered as carbon). This technology cause's harm to the health of producers by inhalation of toxic gases and exposure to high temperatures. It is estimated that domestic consumption of charcoal reaches over 600 thousand ton/year [45]. The improved technologies offer an opportunity to reduce the consumption of wood in the manufacture of charcoal, mitigate greenhouse gas emissions, improve working conditions and the income of farmers, and in general, a more sustainable bioenergy production process.

Brick furnaces: Brick furnaces were originally designed by the Technological Institute of Minas Gerais, Brazil [47], with theobjective of improving the production process over traditional earth kilns. The transfer and adaptation of technology in Mexico has been the responsibility of Nature and Development Civil Association, an 
association started in the city of Queretaro in 2003, with a transferred technology known as "RaboQuente". So far eight states are involved, with around 30 projects, 60 furnaces and 100 direct beneficiaries. Main features are shown in Table 3 [46].

\section{Biofuels}

Biodiesel is a mixture of fatty acid esters with short chain alcohols, resulting from the reaction of vegetable oils or animal fats with methanol or ethanol at atmospheric pressure [48]. It can completely replace petroleum diesel (B100), or be used in mixtures with different percentages $(\mathrm{B} 1, \mathrm{~B} 5, \mathrm{~B} 10)$. Its main advantage is that it can be produced from renewable sources [49]. Particularly, biodiesel is drawing attention from government agencies, since it can be a notable factor for promoting regional development in the country [4]. Biodiesel is expected to replace $7.8 \%$ of conventional diesel fuel consumption by 2031 [50]. Mexican studies have determined that production of biodiesel can be competitive if the following crops are used as feedstock: oil palm tree, sunflower, soy and Jatrophacurcas [51]. There are different projects being developed in Mexico (Table 4).

Bioenergetic Chiapas: This program was operated by the Institute for Agricultural Restructuring and Tropical Agriculture (IRPAT). It included the establishment of plantations, oil extraction and biodiesel production plants. The objective of the program was to establish 20,000 ha of pinion (Jatrophacurcas L.) by 2012 in more than 20 municipalities, which was partially achieved. Biodiesel was also obtained from the oil palm and vegetable oils, and it was intended to supply 113 units of the urban public transport of the state capital, Tuxtla Gutierrez and of the city of Tapachula. These vehicles used B5 and B20, but there was a unit that used B100. In April 2010, two biodiesel plants were installed. One in Tuxtla Gutierrez, with Swedish technology, which produces 2000 L/d; another in Puerto Chiapas, with a module of ColombianMexican technology (whose production is $8000 \mathrm{~L} / \mathrm{d}$ ) and other English technology module (which produced $20000 \mathrm{~L} / \mathrm{d}$ ). Overall, the installed production capacity was $30,000 \mathrm{~L} / \mathrm{d}[29,50]$.

BiocombustiblesInternacionales S.A. de C.V.: The municipality of Cadereyta, Nuevo León holds the first biodiesel production plant in Mexico, with a capacity of 1.5 million liters a month. The main raw materials used are beef tallow and recycled vegetable oils. It began operations in October 2004 and was officially opened in July 2005. The produced biodiesel at the plant is used by PEMEX Refining as an additive of ultra-low sulfur diesel due to its high capacity as a lubricant because it contains no sulfur. The introduction of biodiesel in Mexico would bring out several benefits, such as: job creation, expansion of the facility to rural areas, development of rural economies, conservation of oil resources and development of multiple crops $[4,52]$.

\section{Conclusions}

Energy policy in Mexico has strengthened the development of renewable sources of energy during the last years; however, roadmaps to define its participation in the energy mix are still missing. One of the most promising sources of renewable energy is biomass, which has an estimated potential of 3,569 PJ/year, where almost $50 \%$ would come from the management of native forests. Biomass conversion technologies in Mexico rely mainly on biogas and biofuel production, wood stoves and charcoal furnaces which have representative projects in various states of the country. Three important wood stove types (Patsari, Mexalit and Onil) and one charcoal furnace (RaboQuente) were developed in Mexico. The country has been identified as a pioneer in the landfill biogas energy generation in Latino America. Moreover, the government is mindful of the production of biodiesel to promote regional development in the country, especially in rural communities. Development of this kind of projects will allow the country to reduce gradually its dependence on fossil fuels.

\section{Acknowledgement}

The authors thank the Chair of Environmental Bioprocesses (Tecnológico de Monterrey) for the financial support given during this investigation, to Red Mexicana de Bioenergía A.C. for its great effort to collect information and finally to SolucionesTecnológicas con Microalgas S.A. de C.V. for its support during this study.

\section{References}

1. Alemán-Nava GS, Casiano-Flores VH, Cárdenas-Chávez DL, Díaz-Chavez $\mathrm{R}$, Scarlat N, et al. (2014) Renewable energy research progress in Mexico: Areview. Renew Sustain Energy Rev, 32:140-153.

2. REEEP (2007)Sustainalbe energy policy initiative for Latin Amertrica and the Caribbeanreport.

3. (DOF). DO de la F. Ley de promoción y desarrollo de los bioenergéticos; 2008 n.d.

4. Rangel-Hernández VH, Gómez-Vargas DP, Gallegos-Muñoz A,PlascenciaMora H (2011) The development impact of biodiesel: a review of biodieselproduction in mexico. Int J Energy Environ Eng, 2:91-99.

5. Camara de Diputados. Law for the Use of Renewable Energy and Finance of the Energy Transition. D Of La Fed 2008:1-12.

6. SENER. Anhydrous Ethanol Program Introduction 2011.

7. Network R (2013) Renewables 2013-Global Status Report.

8. SENER (2011) National Energy Balance.

9. Masera O (1993) Sustainable fuelwood use in rural Mexico. Patterns Resour Use, USALawrence Berkeley.

10. INEGI (2009) Estadísticashistóricas de México.

11. The World Bank (2014) World Development Indicators: Rural environment and land use.

12. Castillo-Santiago MÁ, Ghilardi A, Oyama K, Hernández-Stefanoni JL, Torres I, et al. (2013) Estimating the spatial distribution of woody biomass suitable for charcoal making from remote sensing and geostatistics in central Mexico. Energy Sustain Dev 17: 177-88

13. García-Frapolli E, Schilmann A, Berrueta VM, Riojas-Rodríguez H, Edwards RD, et al. (2010) Beyondfuelwood savings: Valuing the economic benefits of introducing improved biomass cookstoves in the Purépecha region of Mexico. EcolEcon 69: 2598-2605

14. Toscano L, Montero G, Stoytcheva M, Campbell H, Lambert A (2011) Preliminaryassessment of biodiesel generation from meat industry residues in Baja California, Mexico. Biomass and Bioenergy 35: 26-31.

15. Sheinbaum-Pardo C, Calderón-Irazoque A, Ramírez-Suárez M (2013) Potential of biodieselfrom waste cooking oil in Mexico. Biomass and Bioenergy 56: 230-238.

16. Murillo Alvarado PE, Ponce Ortega JM, CastroMontoya AJ, Serna González M, El-Halwagi MM (2014) 24th European Symposium on Computer Aided ProcessEngineering. Elsevier.

17. Aguilar Virgen Q, Taboada González P, Ojeda Benítez S, Cruz Sotelo S (2014) Powergeneration with biogas from municipal solid waste: Prediction of gas generation within situ parameters. Renew Sustain Energy Rev 30: 412-419.

18. Aguilar Virgen Q, TaboadaGonzález P, OjedaBenítez S (2014) Analysis of thefeasibilityof the recovery of landfill gas: a case study of Mexico. J Clean Prod 79: 53-60.

19. Halsnæs K (1996) The economics of climate change mitigation in developing countries. Energy Policy 24: 917-26.

20. Pine K, Edwards R, Masera O, Schilmann A, MarrónMares A, Riojas RH (2011) Adoption and use of improved biomass stoves in Rural Mexico. Energy Sustain Dev 15: 176-83

21. Holmes HA, Pardyjak ER, Speckart SO, Alexander D (2011) Comparison 
Citation: Alemán-Nava GS, Sandate-Flores L, Meneses-Jácome A, Díaz-Chavez R, Dallemand JF, et al. (2014) Bioenergy Sources and Representative Case Studies in Mexico. J Pet Environ Biotechnol 5: 190. doi:10.4172/2157-7463.1000190

ofindoor/outdoor carbon content and time resolved PM concentrations for gas andbiomass cooking fuels in Nogales, Sonora, Mexico. Atmos Environ 45: 7600-11.

22. Saatkamp BD, Masera OR, Kammen DM (2000) Energy and health transitions indevelopment: fuel use, stove technology, and morbidity in Jarácuaro, México. Energy Sustain Dev 4: 7-16

23. Aldana H, Lozano FJ, Acevedo J (2014) Evaluating the potential for producing energyfrom agricultural residues in México using MILP optimization. Biomass and Bioenergy 67: 372-389.

24. Energy Information Administration. International energy statistics: Mexico n.d. U.S.A.

25. Islas J, Manzini F, Masera O (2007) A prospective study of bioenergy use in Mexico. Energy 32: 2306-2320.

26. Valdez Vazquez I, Acevedo Benítez JA, Santiago CH (2010) Distribution andpotential of bioenergy resources from agricultural activities in Mexico. Renew Sustain Energy Rev 14: 2147-2153.

27. ECLAC (2008) Statistical Yearbook for Latin America and the Caribbean.

28. ProMéxico. Energías Renovables (2013) Secr Econ.

29. Cerutti OM (2010) La bioenergia en Mexico, casos de estudio.

30. Johnson T, Alatorre C, Zayra R (2009) México: estudiosobre la disminución de emisionesde carbono.

31. REMBIO (2011) Bioenergy in Mexico, current situation and outlook.

32. McKendry P (2002) Energy production from biomass (part 2): conversion technologies. Bioresour Technol 83: 47-54

33. Ryckebosch E, Bermúdez SPC, Termote Verhalle R, Bruneel C, Muylaert K, et al. (2013) Influence of extraction solvent system on the extractability of lipidcomponents from the biomass of Nannochloropsisgaditana. J Appl Phycol 26: $1501-1510$

34. Cuellar-Bermudez SP, Garcia-Perez JS, Rittmann BE, Parra-Saldivar R (2014) Photosynthetic bioenergy utilizing CO2: an approach on flue gases utilization forthird generation biofuels. J Clean Prod.

35. LFGConsult (2007) Case of CDM Landfill Gas Projects Monterrey, Mexico (BENLESA).

36. AGCert (2005) AWMS GHG Mitigation Project MX05-B-09, Nuevo León, México.
37. Global Methane Initiative (2010) Resource Assessment for Livestock and AgroIndustrial Wastes-Mexico.

38. Curry N, Pillay P (2012) Biogas prediction and design of a food waste to energy system forthe urban environment. Renew EnergyT 41: 200-209.

39. Masera O (2010) Patrones de uso de leña en México: situación actual y perspectivas a largoplazo.

40. Fonseca HL (2011) Emisionespor Consumo Doméstico de Leña.

41. Masera O, Edwards R, Arnez CA, Berrueta V, Johnson M, et al. (2007) Impactof Patsari improved cookstoves on indoor air quality in Michoacán, Mexico. Energy Sustain Dev 11: 45-56.

42. Ruiz-Mercado I, Masera O, Zamora H, Smith KR (2011) Adoption and sustained use ofimproved cookstoves. Energy Policy 39: 7557-66.

43. Adkins E, Chen J, Winiecki J, Koinei P, Modi V (2010) Testing institutional biomasscookstoves in rural Kenyan schools for the Millennium Villages Project. Energy Sustain Dev 14: 186-93.

44. Tyagi SK (2013) Design, development and technological advancement in the biomasscookstoves: A review. Renew Sustain Energy Rev 26: 265-85.

45. Bravo R, Cerutti O, Chalico T (2010) Woodfuels and climate change mitigation Casestudies from Brazil, India and Mexico. Clim Chang.

46. Oliveira AC, Salles TT, Pereira BLC, Carneiro A de CO, Braga CS, et al. (2014) Economic viability of charcoal production in two production systems. Floresta 44: $143-52$.

47. Monteiro M (2000) Metallurgy in the Brazilian Amazon: Alternatives for activities withscarce ecological prudence. Pap Do NAEA 157:1-28.

48. Chisti Y (2007) Biodiesel from microalgae. Biotechnol Adv, 25: 294-306

49. Demirbas A (2008) Biofuels sources, biofuel policy, biofuel economy and global biofuelprojections. Energy Convers Manag 49: 2106-16.

50. Lozada I, Islas J, Grande G (2010) Environmental and economic feasibility of palm oilbiodiesel in the Mexican transportation sector. Renew Sustain Energy Rev 14: 486-92.

51. SENER S de E (2006) Potentials and Feasibility use of the Bioethanol and Biodiesel in the Mexican Transport. Secr Energ.

52. Masera O, Rodríguez Martínez N (2006) Potenciales y viabilidaddeluso de bioetanol ybiodiesel para el transporte en México. 